\title{
ANALISA KOMPREHENSIF TRANSPARANSI DALAM PENYELENGGARAAN PEMERINTAHAN DAERAH
}

\author{
Akhmad \\ Dosen Universitas Pejuang Republik Indonesia
}

\begin{abstract}
ABSTRAK
Penelitian ini membahas tentang transparansi yang ada di Pemerintahan Daerah dalam upaya mewujudkan penyelenggaraan pemerintahan yang baik. Permasalahan penelitian ini adalah: 1) bagaimana transparansi dalam penyelenggaraan pemerintahan daerah 2) faktor-faktor apa yang menjadi penghambat transparansi dalam penyelenggaraan pemerintahan daerah dan 3) strategi apa yang tepat digunakan dalam menerapkan transparansi penyelenggaraan pemerintahan daerah. Penelitian ini bertujuan untuk: 1) mendeskripsikan transparansi dalam penyelenggaraan pemerintahan daerah, 2) menganalisa faktor-faktor yang menjadi penghambat transparansi dalam penyelenggaraan pemerintahan daerah, dan 3) menerapkan strategi yang tepat dalam transparansi penyelenggaraan pemerintahan daerah. Hasil penelitian menemukan bahwa transparansi dalam penyelenggaraan pemerintahan sudah berjalan sebagaimana yang diharapkan di bidang anggaran, kepegawaian, pengadaan barang dan jasa. Sumber daya manusia yang bermental korupsi, aturan yang tumpang tindih, sistem keuangan yang lemah, lemahnya penegakan hukum dan masyarakat yang toleran merupakan faktor-faktor yang menjadi penghambat transparansi dalam penyelenggaraan pemerintahan daerah. Strategi transparansi intensif yang tepat digunakan dalam menerapkan transparansi penyelenggaraan pemerintahan daerah. Melalui model ini transparansi penyelenggaraan pemerintahan yang baik dapat diwujudkan sebagai solusi untuk mengatasi permasalahan dinamika aktivitas pemerintah yang tidak transparan dan meminimalisir faktorfaktor yang menjadi penghambat terwujudnya transparansi penyelenggaraan pemerintahan yang baik.
\end{abstract}

Kata Kunci: Transparansi, Faktor Penghambat dan Strategi Transparansi

\section{PENDAHULUAN}

Keberhasilan pembangunan nasional tidak terlepas dari keterlibatan pihak pemerintah dan masyarakat untuk secara bersama-sama melakukan proses pembangunan yang terencana, terarah dan memiliki tujuan. Atas dasar ini maka dibutuhkan andil dari pemerintah dan masyarakat untuk bahu membahu dalam melakukan pembangunan nasional. Salah satu keberhasilan pemerintah dan masyarakat untuk melakukan kegiatan pembangunan nasional tidak terlepas dari kemampuan memahami pemerintahan yang transparan dan dukungan masyarakat untuk mewujudkan pemerintahan yang baik.

Pemerintahan yang transparan atau terbuka merupakan suatu sistem yang dianut oleh Pemerintah dalam menyelenggarakan aktivitasnya terdapat kebebasan aliran informasi dalam berbagai proses kelembagaan dari masing-masing instansi Satuan Kerja Perangkat Daerah 
(SKPD), sehingga mudah diakses oleh setiap lapisan masyarakat. Berbagai informasi yang diadakan, diberikan dan disediakan oleh Pemerintah secara terakses dapat digunakan sebagai alat untuk memonitoring, mengevaluasi dan menilai pekerjaan yang dilakukan oleh pemerintah dibawah pengawasan masyarakat.

Penyelenggaraan pemerintahan daerah setelah era reformasi ini dituntut untuk lebih bersikap transparan terhadap berbagai aktivitas tata kelola pemerintahan yang dibuat oleh pemerintah dan mendapat dukungan dari masyarakat dengan menciptakan segala perangkat dan aturan sistem dan mekanisme kerja pemerintah harus transparan, dapat diinformasikan kepada masyarakat dan masyarakat mudah mengakses segala informasi yang berkaitan dengan tata kelola pemerintahan yang baik sesuai tugas pokok dan fungsi masing-masing instansi pemerintah.

Transparansi pada prinsipnya adalah prinsip penciptaan kepercayaan timbal balik antara pemerintah dan masyarakat melalui penyediaan informasi yang menjamin kemudahan dalam memperoleh informasi yang akurat dan memadai. Melalui transparansi ini, pemerintah dan masyarakat saling memberi informasi di mana informasi merupakan suatu kebutuhan penting bagi pemerintah dan masyarakat untuk saling berpartisipasi dalam menjalankan tata kelola pemerintahan yang baik.

Beranjak dari pemahaman transparansi tersebut, maka Pemerintahan Daerah berupaya untuk mewujudkan transparansi penyelenggaraan pemerintahan daerah dengan melakukan serangkaian aktivitas tata kelola pemerintahan yang baik, sehingga dipercaya oleh masyarakat untuk melakukan pengelolaan pemerintahan yang berpihak kepada masyarakat.

Instrumen dasar dari transparansi penyelenggaraan pemerintahan daerah adalah peraturan perundang-undangan yang menjamin hak setiap warga negara untuk mendapatkan informasi, sedangkan instrumen pendukung terwujudnya transparansi adalah adanya fasilitas database dan sarana informasi yang digunakan untuk menghimpun segala saran, masukan dan pengaduan untuk memperbaiki penyelenggaraan pemerintahan yang baik.

Pemerintahan Daerah telah menyiapkan perangkat tata kelola pemerintahan yang jelas tentang cara mendapatkan informasi yang dibutuhkan oleh masyarakat yang dapat diakses ataupun informasi yang bersifat update yang dibutuhkan masyarakat dan membantu pemerintah untuk memecahkan berbagai permasalahan yang dihadapinya. Melalui instrumen dasar dari transparansi berupa informasi, komunikasi, fasilitas database dan produk/jasa yang berkaitan dengan penyelenggaraan pemerintahan daerah yang baik, maka transparansi merupakan suatu jaminan untuk mengatur tentang hak setiap warga negara untuk memperoleh akses dan penyebarluasan informasi mengenai hasil-hasil kerja dari pemerintah. Karena itu, transparansi dalam pemerintahan menjadi modal dasar bagi pemerintah untuk maju dan berkembang dalam mendapat dukungan dan partisipasi masyarakat menjalankan roda pemerintahan daerah.

Mengingat pentingnya transparansi, menurut Stelent (2008) transparansi merupakan solusi terwujudnya pemerintahan yang baik. Wilson (2007) menyatakan pemerintahan yang baik selalu mengutamakan transparansi. Henry (1995) menyebutkan bahwa transparansi dan pemerintahan yang baik merupakan satu kesatuan yang tidak dapat dipisahkan. Tidak mungkin transparansi dapat diterapkan pada pemerintahan yang tidak baik, dan transparansi mudah 
diterapkan pada pemerintahan yang baik. Atas dasar ini maka menjadi pertimbangan untuk memahami wujud penerapan transparansi dalam penyelenggaraan pemerintahan yang baik.

Pandangan tersebut di atas menjadi pijakan peneliti untuk mengamati fenomena mengenai transparansi yang ada di Pemerintahan Daerah dalam upaya mewujudkan penyelenggaraan pemerintahan yang baik. Permasalahan transparansi yang sering mencuat dipermukaan atau menggejala di kalangan pemerintah dan masyarakat adalah transparansi yang diterapkan di bidang anggaran, bidang kepegawaian dan bidang pengadaan barang dan jasa. Ketiga bidang yang ada di pemerintahan ini sering mendapat sorotan, protes, keluhan dan antipati dari masyarakat mengenai bidang yang dikerjakan oleh pemerintah yang tidak transparan dalam pemberian informasi, komunikasi, akses data, dokumen dan berbagai pelaporan yang tidak dapat dinilai oleh masyarakat.

Beranjak dari fenomena ketidaktransparansian yang dilakukan oleh pemerintah pada bidang anggaran, kepegawaian dan pengadaan barang dan jasa, menimbulkan efek ketidakpercayaan, ketidaksesuaian, ketidakpastian dan tidak adanya jaminan dari pemerintah untuk mewujudkan pemerintahan yang baik. Hal ini dapat tercermin dari kebiasaan pemerintah yang tidak mendengar suara masyarakat atau mengabaikan segala masukan masyarakat atas kegiatan pelaksanaan tugas dan fungsi pemerintah dalam menjalankan bidang yang dipermasalahkan tersebut.

Kenyataan yang terlihat di bidang anggaran memperlihatkan bahwa Pemerintah sering tidak transparan dalam memberikan informasi, akses dan dokumen kepada masyarakat yang berkaitan dengan perolehan sumber pendapatan, pengeluaran dan pembiayaan pendapatan yang berasal dari anggaran negara dan daerah yang digunakan. Hal yang sering menjadi tidak transparan di bidang anggaran adalah usulan Kebijakan Umum Anggaran (KUA), Prioritas dan Plafond Anggaran Sementara (PPAS) serta tahap pembahasan Rancangan Anggaran Pendapatan dan Belanja Daerah (RAPBD). Di bidang anggaran tersebut pihak masyarakat sering mencurigai berbagai informasi yang tidak transparan, bisa dilakukan oleh pihak pemerintah sebagai eksekutif dan pihak Dewan Perwakilan Rakyat Daerah (DPRD) sebagai legislatif untuk melakukan rekayasa informasi atau penyalahgunaan anggaran sesuai dengan informasi yang dibuat secara sepakat, sehingga pengelolaan bidang anggaran yang dijalankan tidak transparan diterima oleh masyarakat.

Selain itu disinyalir oleh banyak pihak masyarakat bahwa transparansi di bidang kepegawaian sering terjadi praktek Korupsi, Kolusi dan Nepotisme (KKN) khususnya ketidaktransparansian dalam kegiatan rekruitmen pegawai negeri sipil, mutasi kerja pegawai dan pemberian kompensasi yang terkadang tidak sesuai dengan kebijakan dan aturan yang berlaku. Transparansi di bidang kepegawaian sering diintervensi oleh pihak-pihak penguasa yang memiliki kepentingan tertentu dan mencari keuntungan pribadi dari ketidaktransparansian. Memahami hal ini maka masyarakat sering protes dan mengelukan gejala ketidaktransparansian yang dilakukan oleh pemerintah dengan tidak memberikan informasi, data dokumen secara legalitas hukum.

Termasuk pula dalam hal ini kegiatan yang dilakukan oleh pemerintah yang sering mendapat sorotan dari masyarakat yaitu yang menyangkut ketidaktransparansian dalam pengadaan barang dan jasa, di mana pihak pemerintah sering mengusulkan pengadaan barang 
dan jasa yang tidak sesuai dengan peruntukannya, melakukan berbagai kegiatan mark up untuk mendapatkan keuntungan, memanipulasi data inventaris permintaan dan penawaran barang dan jasa, ada permainan konspirasi KKN antara pihak pemerintah dengan pengusaha atau pedagang dalam pengadaan barang dan jasa, sehingga banyak informasi, data dan dokumen yang tidak transparan yang menjadi permasalahan dalam mewujudkan transparansi penyelenggaraan pemerintahan yang baik.

Terjadinya fenomena ketidaktransparansian di bidang anggaran, kepegawaian, pengadaan barang dan jasa, tentu menjadi sebuah fakta yang harus diungkap berdasarkan kenyataan yang dapat diamati dan disaksikan dalam berbagai pelaksanaan tugas pokok dan fungsi pegawai pemerintah. Penyebab terjadinya ketidaktransparansian pada berbagai bidang yang disebutkan di atas, hal ini terjadi karena ada faktor-faktor yang menghambat terwujudnya transparansi penyelenggaraan pemerintahan daerah yang bersih, berwibawa dan bertanggungjawab.

Berdasarkan pengamatan yang ditemukan di dunia pemerintahan bahwa faktor penghambat transparansi biasanya dikarenakan sumber daya yang ada di pemerintahan banyak yang bermental korupsi, pegawai pemerintah selalu mengabaikan dan melanggar aturan, sehingga terjadi tumpang tindih aturan yang diterapkan, selain itu sistem pengelolaan keuangan yang lemah, penegakan hukum yang menyimpang serta adanya sekelompok masyarakat yang toleran mendukung budaya yang tidak transparan.

Berikut dijelaskan mengenai sumber daya manusia dari pegawai yang bermental korupsi yang sering melakukan tugas dan fungsinya dengan tidak transparan. Akibatnya banyak pelaksanaan tugas dan fungsi yang menyimpang, tidak sesuai dengan sistem dan mekanisme yang berlaku, melakukan rekayasa dan membuat berbagai penyimpangan yang merugikan negara dan masyarakat. Selain itu, faktor penghambat transparansi penyelenggaraan pemerintah daerah dapat terjadi karena aturan kerja atau peraturan pelaksanaan tupoksi sering tumpang tindih, sehingga dijadikan celah untuk melakukan hal-hal yang tidak transparan untuk mendapatkan keuntungan pribadi dari oknum yang ada di pemerintahan.

Termasuk faktor yang menghambat transparansi penyelenggaraan pemerintahan yang baik adalah pelaksanaan sistem pengelolaan keuangan yang tidak transparan, khususnya yang berkaitan dengan pengadaan sumber-sumber pendapatan, pengeluaran dan pembiayaan keuangan yang sering terjadi penyimpangan, kebocoran dan penyalahgunaan karena rendahnya penerapan transparansi yang dilakukan oleh pihak pemerintah dan menjadikan sulit bagi masyarakat untuk mengawasi hal tersebut karena tidak mendapatkan informasi dan data yang akurat dari pihak pemerintah.

Disisi lain faktor yang menghambat terwujudnya transparansi penyelenggaraan pemerintah adalah lemahnya penegakan hukum untuk pihak yang melakukan pelanggaran dan pengabaian hukum, sehingga tidak ada efek jera yang menyebabkan oknum pemerintah untuk melakukan hal-hal yang tidak transparan. Selain itu, masih ditemukan di kalangan masyarakat dalam prakteknya menjadikan kebiasaan atau budaya untuk sering memberi kepada aparat atas berbagai pelayanan atau pelaksanaan kerja meski memiliki motif sebagai balas jasa, namun hal tersebut menjadi kebiasaan buruk yang dapat menghambat terwujud transparansi pemerintahan yang baik. 
Melalui pemahaman tentang faktor yang menghambat terdiri dari sumber daya manusia yang bermental korupsi, aturan yang tumpang tindih, sistem keuangan yang tidak terkelola dengan baik, penegakan hukum yang lemah dan toleransi masyarakat yang menjadikan kebiasaan memberi kepada oknum pegawai pemerintah menjadi faktor penghambat sulitnya transparansi terwujud dengan baik. Karena itu diperlukan suatu strategi penerapan transparansi penyelenggaraan pemerintahan yang baik.

Strategi penerapan transparansi penyelenggaraan pemerintahan dari yang perlu diterapkan untuk mewujukan transparansi yang bersih, berwibawa dan bertanggungjawab, adil dan merata, maka dapat diterapkan strategi penguatan kelembagaan, strategi perbaikan profesionalisme SDM, melakukan strategi pengawasan dan akuntabilitas serta mendorong penerapan strategi persaingan yang sehat dalam bekerja. Strategi ini penting dalam rangka mewujudkan transparansi pemerintahan baik.

Strategi penguatan kelembagaan diperlukan untuk mengupayakan terwujudnya transparansi pada masing-masing SKPD pemerintah. Wujud dari strategi penguatan kelembagaan tersebut adalah upaya untuk melakukan koordinasi, kerjasama dan perbaikan hubungan kerja antar organisasi, antar kelompok instansi dan antar kelompok tujuan sasaran dalam rangka menghindari sistem dan prosedur kerja yang tidak transparan yang biasa dilakukan oleh oknum pemerintah.

Strategi profesionalisme SDM juga merupakan suatu upaya untuk mewujudkan transparansi dapat dilakukan oleh setiap pegawai yang ada di instansi pemerintah untuk profesional dalam menjalankan aktivitas kerjanya sesuai dengan kompetensi dan profesionalisme kerja yang dimiliki, sehingga mengurangi adanya kesenjangan praktek-praktek kerja yang tidak transparan.

Selain strategi tersebut di atas, perlu juga diterapkan strategi pengawasan dan akuntabilitas kepada setiap pegawai dari masing-masing SKPD instansi pemerintah untuk diawasi secara langsung dan tidak langsung, dan diminta pertanggungjawaban secara langsung dan tidak langsung atas segala kegiatan pelaksanaan tugas dan fungsi yang harus dilakukan secara transparan guna memperbaiki tata kelola pemerintahan yang terawasi dan bertanggungjawab.

Termasuk strategi yang perlu diterapkan dalam upaya mewujudkan transparansi penyelenggaraan pemerintahan daerah yaitu menerapkan strategi persaingan yang sehat bagi setiap pegawai di masing-masing SKPD untuk menduduki jabatan struktural, fungsional dan teknis melalui suatu persaingan yang sehat di antara para pegawai dalam menjalankan tugas dan fungsi di pemerintahan. Melalui persaingan yang sehat untuk berkompetensi dan berprestasi dalam rangka mengurangi dan menghindari terjadinya aktivitas kerja yang tidak transparan dari oknum pemerintah yang menjalankan kegiatan secara tidak transparan.

\section{KAJIAN TEORI}

Sebelum menjelaskan mengenai konsep transparansi dalam penyelenggaraan pemerintahan daerah, maka terlebih dahulu dijelaskan dasar pijakan kajian transparansi itu sendiri. Kajian transparansi merupakan lingkup dari kajian ilmu administrasi publik. Menjadi 
penting untuk dipahami keberadaan konsep transparansi sebagai bagian dari aplikasi administrasi publik. Karena itu perlu dipahami terlebih dahulu mengenai teori administrasi publik.

Teori administrasi tidak terlepas dari konstruksi administrasi publik. Rakhmat (2009:29) menyatakan arti dan fungsi konstruksi teori administrasi publik yang dipelajari jauh lebih dari hanya sekadar memahami berbagai pemikiran dari orang yang dikenal sebagai ahli administrasi yang melahirkan berbagai teori administrasi, yang seakan-akan pemikirannya merupakan suatu kebenaran yang terakhir. Teori sesungguhnya selalu berkembang dan tidak mengenal akhir.

Ilmu pengetahuan mencakup lapangan yang sangat luas dan bersifat multidimensional, menjangkau semua aspek tentang kemajuan manusia secara keseluruhan. Karena itu, pengetahuan yang telah dirumuskan secara sistemik melalui pengamatan dan percobaan yang terus menerus, dan telah menghasilkan penemuan kebenaran yang bersifat universal. Dengan demikian ciri utama dari sebuah ilmu adalah memiliki teori (Rakhmat, 2009:36).

Sebelum menjelaskan tentang konsep transparansi dirasa perlu menelaah tentang konsep tata kelola pemerintahan yang baik atau bisa disebut Good Governance. Konsep Good Governance sesungguhnya masih diperdebatkan dan berkembang terus dalam berbagai perbincangan akademik. Pada awalnya Bank Dunia mendefenisikan - Governance- sebagai - the exercise of political power to manage a nations affair (Davis and Keating, 2000). Bank Dunia juga menambahkan karakteristik normative tentang Good Governance, yaitu: "An efficient public service, and independent judicial system and legal frame work to enforce contract; the accountable administration of public funds; an independent public auditor, responsible to a representative legislature; respect for law and human rights at all levels of government; a pluralistic institutional structure; and free press".

Sementara itu UNDP mendefenisikan Good Governance sebagai "The Exercise of political, economic, and administrative authority to manage the nation "s affair at all levels. OECD dan WB mensinonimkan Good Governance dengan penyelenggaraan manajemen pembangunan yang solid dan bertanggung jawab sejalan dengan demokrasi dan globalisasi, penghindaran salah alokasi dana investasi yang langka, dan pencegahan korupsi baik secara politik maupun administratif, menjalankan disiplin anggaran serta menciptakan kepastian hukum dan suasana politik untuk tumbuhnya aktivitas kewirausahaan.

Dalam era reformasi dimana pilar-pilar Good Governance telah menjadi sesuatu yang urgen dalam kehidupan berbangsa dan bernegara, maka saat itu pula transparansi penyelenggaraan pemerintahan sudah menjadi kebutuhan yang tidak dapat diabaikan lagi. Persoalan pokok dan menjadi sebuah pertanyaan dalam kajian ini adalah mengapa perlu transparansi dalam Good Governance? Untuk itu, sebelum lebih jauh berupaya menemukan format dan konsep transparansi mungkin pertanyaan di atas perlu dijawab terlebih dahulu.

Pemerintah yang bertanggung jawab adalah pemerintah yang mampu menjawab atau memenuhi janji kepada publik maupun konstituennya. Untuk mewujudkan pertanggungjawaban pemerintah terhadap publik, maka salah satu cara dilakukan adalah dengan menggunakan prinsip-prinsip transparansi (keterbukaan). Transparansi penyelenggaraan pemerintahan memiliki arti yang sangat penting dimana masyarakat diberikan kesempatan untuk mengetahui kebijakan yang akan dan telah diambil oleh pemerintah. Bahkan dengan transparansi 
penyelenggaraan pemerintahan tersebut, masyarakat dapat memberikan feedback atau outcomes terhadap kebijakan yang telah diambil oleh pemerintah.

Ini berarti bahwa transparansi dalam penyelenggaraan pemerintahan dapat memberikan makna yang sangat berarti yakni disamping sebagai salah satu wujud pertanggung jawaban pemerintah kepada rakyat, kecuali itu pula dapat menciptakan penyelenggaraan pemerintahan yang baik atau good governance dan juga dapat mengurangi kesempatan praktek kolusi, korupsi dan nepotisme (KKN). Disinilah kuncinya mengapa transparansi sangat diperlukan dalam Good Governance bahkan merupakan salah satu syarat penting. Mungkin masih segar dalam ingatan, bahwa salah satu yang menjadi persoalan diakhir masa masa orde baru adalah merebaknya kasus-kasus korupsi. Dan salah satu yang dapat menimbulkan dan memberi ruang gerak kegiatan ini adalah manajemen pemerintah yang tidak transparan.

Penerapan transparansi dalam penyelenggaaan pemerintahan daerah dimaksudkan agar setiap aktivitas penyelenggaraan pemerintahan dilakukan melalui pemberian informasi secara terbuka dan terawasi oleh semua pihak termasuk dalam hal ini adalah masyarakat. Keterbukaan informasi dan pengawasan yang luas menjadi penting untuk mewujudkan transparansi dalam penyelenggaraan pemerintahan daerah. Menurut Sedarmayanti (2008:57) transrapansi dalam penyelenggaraan pemerintahan daerah harus bersifat terbuka, terakses, bertanggungjawab dan dapat memberikan informasi sesuai kejelasan dan diawasi secara luas oleh semua pihak yang terlibat dalam penyelenggaraan pemerintahan daerah.

Transparansi merupakan instrumen penting untuk mewujudkan pemerintahan yang baik, bersih dan berwibawa. Transparansi merupakan inti dari konsep good governance. Aktualisasi dari transparansi adalah keterbukaan, pertanggungjawaban, akses informasi yang jelas dan dapat dinilai secara luas oleh semua pihak dalam rangka mewujudkan penyelenggaraan pemerintahan yang baik. Dwiyanto (2008:75) menyatakan transparansi menjadi inti keberhasilan penyelenggaraan pemerintahan yang baik, bersih dan berwibawah sangat tergantung pada: 1) transparansi pengelolaan anggaran pemerintah; 2) transparansi pengelolaan perilaku pemerintah; dan 3 ) transparansi pengadaan barang dan jasa pemerintah. Ketiga wujud transparansi ini sangat menentukan berhasil tidaknya penyelenggaraan pemerintahan.

Permasalahan umum pada birokrasi di Indonesia tersebut dan fakta yang dijumpai, mengidentifikasikan faktor-faktor penghambat terimplementasikannya asas transparansi dalam pelayanan publik sebagai berikut:

Kurangnya kompetensi SDM aparatur diawali dari rekrutmen yang tidak benar karena sistem rekrutmen yang buruk. Hal ini berlanjut dengan pembinaan SDM yang juga tidak baik. Banyaknya kasus tentang terjadinya praktik KKN dalam perekrutan CPNS di berbagai instansi dan di pemerintah daerah menunjukkan buruknya sistem rekrutmen PNS. Pengangkatan hampir satu juta tenaga honor menjadi PNS yang tidak melalui proses seleksi merupakan contoh nyata pengabaian kompetensi. Jika hal ini diimbangi dengan pembinaan yang baik, maka akan dapat mengurangi dampak buruknya. Namun jika tidak diikuti dengan pembinaan yang memadai, maka dampaknya akan sangat buruk di masa yang akan datang.

Penghilangan tumpang tindih tersebut menyebabkan seorang pejabat menyamarkan atau menyembunyikan tugas dan fungsinya dengan menonjolkan wewenangnya. Hal ini jelas 
38|Ad'ministrare, Vol. 3 No. 2, 2016

bertentangan dengan asas transparansi. Tumpang tindihnya peraturan perundangan ini banyak dipengaruhi juga oleh faktor politis dan legislatif maupun dari eksekutif sendiri.

Sistem pengawasan, monitoring, dan evaluasi yang lemah tidak akan dapat mengungkap kelemahan maupun penyimpangan yang terjadi pada suatu kegiatan, termasuk tidak dipatuhinya ketentuan dan keharusan untuk mengimplementasikan asas transparansi.

Sering dijumpai adanya penyimpangan yang tidak diambit tindakan yang selayaknya, dengan berbagai pertimbangan. Hal ini mengakibatkan kesalahan serupa dapat terjadi secara berulang. Hasil pengawasan, termasuk pengawasan masyarakat berupa pengaduan yang tidak ditindaklanjuti akan menjadikan pengawasan itu sendiri tidak ada manfaatnya. Hal ini menjadikan masyarakat apatis sehingga pengawasan masyarakat menjadi tidak berfungsi.

Hal ini banyak terjadi mana kala masyarakat sudah merasa terbiasa dengan terjadinya penyimpangan yang tidak pernah ditindak. Dengan demikian maka pengawasan masyarakat tidak akan lagi berfungsi sebagaimana seharusnya. Hal ini juga disebabkan pemahaman nilainilai luhur agama yang salah.

Strategi penerapan transparansi pemerintahan daerah melalui beberapa aspek yang menjadi faktor pendorong transparansi yaitu pertama, penguatan kelembagaan. Kelembagaan yang tepat fungsi dan tepat ukuran dan tidak tumpang tindih dengan jelas akan dapat diindentifikasi siapa yang harus bertanggung jawab bahkan yang perlu diberikan sanksi apabila terjadi penyimpangan ataupun kegagalan pencapaian target kinerja.

Kedua, profesionalisme (SDM), sebagian dan PNS terdapat aparat yang selalu menjaga profesionalismenya. Pihak inilah yang harus dijaga dan dikembangkan dengan memberikan reward yang semestinya, sehingga dapat diikuti oleh PNS yang lain. Ketiga, pengawasan dan akuntabilitas uang dengan diikuti sistem reward \& punishment. Beberapa instansi telah melaksanakan sistem money yang bag us, sehingga kinerja instansi tersebut cukup bagus. Komitmen inilah yang perlu ditularkan ke instansi lain. Dan keempat, persaingan yang sehat (lingkungan). Persaingan di antara pemerintah daerah dalam hal-hal tertentu akan mendorong masing-masing untuk meningkatkan kinerjanya (pelayanan publik) dengan selalu melakukan perbaikan melalui akomodasi terhadap setiap masukan, terutama dari masyarakat pengguna layanan. Penilaian kinerja dari sektor tertentu oleh Lembaga lndependen secara tidak langsung akan mendorong persaingan antar pemerintah daerah dan instansi untuk mencapai peringkat yang diinginkan Menpan juga diamanatkan undang-undang untuk menyusun peringkat penyelenggara layanan publik, yang selama ini dilakukan dengan pemberian penghargaan citra Pelayanan Prima. Hal ini juga akan meramaikan tingkat persaingan di antara para penyelenggara layanan publik.

\section{HASIL DAN PEMBAHASAN}

Menjelaskan eksistensi dan substansi dari transparansi penyelenggaraan pemerintahan daerah secara mendetail tentang penerapan transparansi di bidang anggaran, transpransi bidang kepegawaian, transparansi bidang pengadaan barang dan jasa, yang tidak terlepas dari faktor 
yang menghambat terwujudnya transparansi dapat diterapkan dengan baik. Faktor-faktor penghambat transparansi berdasarkan hasil penelitian ini terdiri dari mental SDM, peraturan yang tumpang tindih, sistem keuangan yang tidak terkelola baik, penegakan hukum yang lemah dan masyarakat yang toleran untuk melakukan praktek-praktek yang tidak mendukung penguatan transparansi. Karena itu diperlukan suatu strategi penerapan transparansi melalui strategi penguatan kelembagaan, profesionalisme SDM, pengawasan dan akuntabilitas serta persaingan yang sehat.

Transparansi yang diterapkan dalam penelitian ini adalah transparansi penyelenggaraan pemerintahan daerah, di mana transparansi yang dimaksud dalam penelitian ini adalah keterbukaan akses bagi masyarakat dalam memperoleh informasi mengenai berbagai kegiatan yang dilakukan oleh pemerintah. Transparansi dalam penelitian ini merupakan prinsip yang menjamin akses atau kebebasan bagi setiap orang untuk memperoleh informasi tentang penyelenggaraan pemerintahan yakni informasi tentang tata kelola pemerintahan, informasi tentang pelaksanaan tugas pokok dan fungsi pemerintah, proses penyelenggaraan pemerintah pada berbagai bidang kerja.

Transparansi yang diterapkan dalam penelitian ini adalah keterbukaan pemerintah dalam membuat sebuah tata kelola yang baik dalam penyelenggaraan pemerintahan, sehingga setiap proses tata kelola pemerintahan yang dilakukan dapat diketahui oleh masyarakat. Transparansi pada akhirnya menciptakan pemerintahan yang bersih, berwibawa, adil dan merata.

Transparansi yang dijalankan pemerintah dalam memberikan informasi yang terkait dengan aktivitas tata kelola pemerintah secara umum dan tata kelola pemerintahan secara khusus pada bidang anggaran, kepegawaian dan pengadaan barang dan jasa. Pada prinsipnya tujuan transparansi dalam penyelenggaraan pemerintahan daerah dilakukan bertujuan untuk: 1) mewujudkan pertanggungjawaban pemerintah dalam melakukan tata kelola pemerintahan kepada masyarakat; 2) upaya meningkatkan kepercayaan masyarakat terhadap kemampuan pemerintah dalam melakukan manajemen tata kelola pemerintahan yang baik; dan 3) sebagai upaya untuk meningkatkan kemampuan pemerintah menyelenggarakan pemerintahan yang tidak korupsi, kolusi dan nepotisme.

Berdasarkan pembahasan yang diuraikan di atas, ini didukung oleh teori transparansi yang dikemukakan oleh Frederickson (2007) bahwa transparansi dilakukan secara sungguhsungguh, menyeluruh dan memberi tempat bagi partisipasi aktif seluruh lapisan masyarakat dalam proses tata kelola pemerintah dan publik. Teori ini menegaskan bahwa transparansi diperlukan berdasarkan partisipasi pemerintah dan publik untuk melakukan tata kelola pemerintahan yang baik.

Hal yang berbeda mengenai pandangan tentang transparansi yang dikemukakan oleh Leach and Perry (2001) bahwa transparansi diartikan keterbukaan dan kejujuran kepada masyarakat berdasarkan pertimbangan bahwa masyarakat memiliki hak untuk mengetahui secara terbuka dan menyeluruh atas pertanggungjawaban pemerintah yang dipercayakan menurut ketentuan dan peraturan perundang-undangan. Ini sejalan dengan pandangan yang dikemukakan oleh Safeii (2002) bahwa transparansi adalah bentuk kepercayaan publik terhadap pertanggungjawaban aktivitas yang dilakukan sesuai dengan aturan. 
Memahami pentingnya transparansi dalam penyelenggaraan pemerintahan daerah, didukung oleh penerapan teori dimensi transparansi yang dikemukakan oleh Billist (2009) di mana teori ini memiliki prinsip bahwa setiap orang berhak untuk mendapatkan jaminan akses kebebasan memperoleh informasi dan data serta pelaporan tentang penyelenggaraan pemerintahan. Informasi, perihal kebijakan, kegiatan tata kelola, pembuatan kebijakan, pelaksanaan dan hasil kerja yang dicapai merupakan bagian penting dari proses penyelenggaraan transparansi.

Pada intinya transparansi menyangkut hal-hal yang bersifat keterbukaan, kebebasan dan aturan yang berlaku harus diketahui oleh semua lapisan masyarakat tentang suatu tinjauan mengenai aturan dan prinsip penyelenggaraan pemerintahan. Menurut Shah (2008) transparansi merupakan peristiwa atau kejadian yang bebas dan terbuka diketahui oleh khalayak umum. Smith (2004) menyatakan transparansi merupakan keterusterangan yang sesuai dengan kenyataan atas informasi yang disampaikan dan dapat dipertanggungjawabkan kebenarannya.

Memahami pengertian transparansi dari dukungan pendapat para ahli ini relevan dengan penerapan transparansi penyelenggaraan pemerintahan yang berkaitan dengan transparansi bidang keuangan, transparansi bidang kepegawaian dan transparansi di bidang pengadaan barang dan jasa. Rondinelli (2001) menyatakan transparansi anggaran adalah keterbukaan atas berbagai informasi, data dan dukungan serta pelaporan yang dapat dipelajari dan dinilai oleh khalayak umum untuk diinterpretasikan secara jujur dan dapat dipercaya. Caiden (2006) mengemukakan bahwa transparansi anggaran adalah aktivitas kegiatan penilaian, perhitungan dan pelaporan kegiatan anggaran keuangan yang dilakukan sesuai peristiwa, kejadian dan transaksi yang terjadi dalam sistem dan prosedur keuangan.

Pemahaman tentang transparansi kepegawaian, ini sejalan dengan teori transparansi model manusia dari Simon (2008) bahwa setiap manusia membutuhkan transparansi dalam menilai model kemampuannya sesuai dengan interpretasi dan keterbukaan tentang kompetensinya, keahlian dan profesionalisme kerja. Atas dasar itu maka setiap orang harus mampu mengembangkan potensinya secara transparan untuk diketahui kompetensi, keahlian dan profesionalisme yang dimilikinya. Hal ini penting untuk memudahkan dalam menilai kelayakan rekruitmen seseorang untuk dapat dimutasi oleh suatu jabatan yang strategis untuk dapat dinilai sesuai dengan besarnya kompetensi yang layak dan pantas diterima oleh seseorang.

Selain itu pemahaman transparansi pengadaan barang dan jasa ini didukung oleh teori kekayaan organisasi dari Halperin (2007) yang menyatakan bahwa aset organisasi berupa barang dan jasa adalah kekayaan organisasi yang harus dimanfaatkan untuk mencapai tujuan organisasi. Ini artinya keberadaan pengadaan barang dan jasa sangat diperlukan sebagai aset penting bagi organisasi. Henry (1995) menyatakan bahwa aset berupa barang dan jasa adalah modal dasar organisasi untuk mewujudkan tujuannya. Ini berarti pengadaan barang dan jasa sangat diperlukan untuk kelangsungan hidup organisasi, tetapi harus diterapkan secara transparan, sehingga memberi kemudahan untuk menilai pemanfaatan dan penggunaan aset untuk mewujudkan tujuan organisasi.

Penerapan transparansi penyelenggaraan pemerintahan daerah yang dilakukan di Pemerintah Daerah, tidak terlepas dari faktor yang mendukung dan menghambat. Faktor yang mendukung menjadi tidak penting untuk diamati, karena tidak menimbulkan permasalahan 
Akhmad, Analisa Komprehensif Transparansi Dalam Penyelenggaraan Pemerintahan Daerah |41

dalam penerapan transparansi, tetapi faktor yang menghambat menjadi penting untuk diamati, supaya dalam penanganan transparansi dapat diatasi dan dikendalikan untuk mewujudkan transparansi penyelenggaraan pemerintahan yang baik.

Faktor penghambat transparansi penyelenggaraan pemerintahan daerah tentu banyak faktor, namun faktor yang urgen ditemukan dalam berbagai dinamika kehidupan pemerintahan selalu berkaitan dengan faktor keberadaan sumber daya manusia yang bermental korupsi, penerapan aturan yang selalu mengalami tumpang tindih, penerapan sistem keuangan yang lemah, lemahnya penegakan hukum dan kebiasaan masyarakat yang toleran untuk melakukan tindakan yang tidak transparan dengan pihak pemerintah.

Memahami tentang faktor penghambat terwujudnya transparansi pemerintahan yang baik tidak terlepas dari faktor seperti yang dikemukakan oleh Flippo (2008) bahwa ada lima faktor penghambat terwujudnya transparansi dalam penyelenggaraan pemerintah. Faktor-faktor ini, bila tidak diantisipasi atau ditangani secara baik dapat mempengaruhi aktivitas organisasi dijalankan dengan tidak transparan.

Setelah penerapan transparansi penyelenggaraan pemerintahan yang baik dalam transparansi bidang anggaran, kepegawaian, pengadaan barang dan jasa, dengan berbagai faktor yang menghambat terwujudnya transparansi dari faktor SDM yang bermental korupsi, peraturan yang tumpang tindih, sistem keuangan yang lemah, penegakan hukum dan masyarakat yang toleran atas kebiasaan memberi dan menerima sebagai faktor penghambat yang harus disikapi dan diperbaiki untuk mewujudkan transparansi pemerintahan yang baik, sehingga perlu ada strategi transparansi untuk digunakan dalam mewujudkan transparansi yang mudah diterapkan oleh pemerintah dan bagi masyarakat untuk mendapatkan berbagai informasi, data, dokumen dan laporan berbagai perihal atas pelaksanaan tugas pokok dan fungsi pemerintah yang dijalankan secara transparan.

Penerapan strategi yang diterapkan untuk mewujudkan transparansi pemerintahan yang baik meliputi strategi penguatan kelembagaan, strategi perbaikan profesionalisme SDM pemerintah, strategi pengawasan dan akuntabilitas serta strategi pengembangan persaingan yang sehat diantara pegawai pemerintah dalam menjalankan tupoksi yang transparan. Wujud dari strategi transparansi ini dapat memecahkan berbagai permasalahan transparansi pemerintahan melalui sosialisasi yang baik diterapkan pada Pemerintah Daerah.

Strategi dilihat berdasarkan tujuan dan sasaran yang ingin dicapai. Chandler dalam Salusu (2005) menyatakan bahwa strategi didefisinikan sebagai penetapan dari tujuan dan sasaran jangka panjang suatu organisasi serta menggunakan serangkaian tindakan dan alokasi sumber daya yang diperlukan untuk mencapai tujuan organisasi. Menurut Mc Nichols (2000) ada empat atribut penting dalam suatu organisasi untuk mengujudkan transpransi yaitu keterampilan, sumber daya, sasaran dan lingkungan.

Shirley dalam Salusu (2005) menyatakan strategi merupakan bagian keseluruhan tindakan yang ditetapkan sebagai aturan yang telah direncanakan oleh suatu organisasi. Ini sama dengan apa yang dikemukakan oleh Learned et al dalam Salusu (2005) bahwa strategi adalah pola tujuan yang dilaksanakan sesuai maksud dan sasaran, berdasarkan kebijaksanaan umum dan perencanaan. Steiner dan Miner (2000) menyatakan bahwa pada dasarnya strategi adalah tindakan untuk mengembang misi, tujuan dan sasaran organisasi yang juga menjalankan 
kebijakan sesuai program dan menjamin terwujudnya perencanaan dalam pengambilan keputusan organisasi secara transparan.

Penerapan strategi dari beberapa pendapat para ahli yang dikemukakan di atas, menjadi sebuah perbandingan untuk menerapkan strategi transparansi yang tepat dalam penyelenggaraan Pemerintahan Daerah sebagai usulan penelitian yang bersifat solusi atas permasalahan ketidaktransparansian penyelenggaraan pemerintah daerah, sehingga perlu diterapkan "Transparansi Parsial".

Penerapan model strategi "Transparansi Parsial" ini dimaknai bahwa dalam penerapan transparansi perlu dilakukan secara parsial, utamanya transparansi di bidang keuangan, bidang kepegawaian dan bidang barang/jasa. Penerapan strategi "Transparansi Parsial" menjadi penting dalam penyelenggaraan pemerintahan yang transparan, di mana pemerintah harus menyediakan akses informasi yang mudah, sederhana dan tidak berbelit-belit bagi semua pihak baik pemerintah, masyarakat dan stakeholder lainnya. Ini penting melalui akses tersebut berbagai hal yang berkaitan dengan kegiatan yang dilakukan oleh pemerintah daerah dapat diketahui, dikaji, dilaporkan dan diawasi, sehingga kegiatan penyelenggaraan pemerintahan dapat berjalan dengan akses informasi yang transparan.

Transparansi penyelenggaraan pemerintahan dalam penerapannya membutuhkan dukungan penuh atau empati dari publik atau masyarakat, karena itu empati menajdi penting dalam mewujudkan transparansi. Arti penting empati dalam transparansi adalah tumbuhnya kemampupahaman atau timbulnya inisiatif untuk melakukan berbagai kegiatan penyelenggaraan pemerintahan yang berpihak kepada kepentingan umum dan mengutamakan keberpihakan kepada publik atau masyarakat, sehingga segala aktivitas pemerintahan mendapat empati dari seluruh pihak.

Mewujudkan transparansi penyelenggaraan pemerintahan tidak terlepas dari andil moral dari setiap orang yang terlibat dalam penyelenggaraan pemerintahan. Moral dari setiap orang merupakan nilai etis yang sangat penting dalam penerapan transparansi. Melalui moral yang transparan menjadi nilai tambah dalam membangun kepercayaan publik untuk dapat melaksanakan segala aktivitas pemerintahan secara transparan dengan mengamalkan nilai moral yang etis sesuai dengan kepantasan, kelayakan dan proporsional dalam mengembang tugas sebagai amanah untuk dilakukan secara transparan.

Mengembang suatu tugas untuk mewujudkan transparansi penyelenggaraan pemerintahan yang baik, dapat berlangsung bila setiap pengambilan keputusan yang dilakukan secara aspiratif. Penerapan transparansi harus dilakukan secara aspiratif sebagai sebuah proses demokrasi untuk mendengarkan atau menerima segala masukan aspirasi publik yang berdampak pada keyakinan atau kepercayaan bahwa pemerintah menjalankan penyelenggaraan pemerintahan dilakukan secara aspiratif dari publik dan untuk publik.

Mewujudkan terselenggaranya transparansi yang baik, tidak terlepas dari pentingnya aspek notulen yaitu sebuah catatan yang berisi dokumen-dokumen penting yang harus diinformasikan, dilaporkan dan dipertanggungjawabkan segala bentuk aktivitas yang dilakukan oleh pemerintah secara transparan dan hal tersebut tercatat dan dijadikan dokumen penting untuk mengevaluasi atau menilai berbagai masukan, kritikan, saran dan usulan dari setiap 
masyarakat mulai dari tingkat desa, kecamatan dan instansi pemerintah dan swasta yang mendukung terwujudnya transparansi penyelenggaraan pemerintahan yang baik.

Memahami strategi "Transparansi Parsial", maka dukungan pemerintah, masyarakat dan stakeholder lainnya untuk melakukan aktivitas transparansi baik di bidang keuangan, kepegawaian dan barang/jasa harus dilakukan dengan mempertimbangkan transparansi yang terakses, transparansi yang berempati pada kepentingan publik, transparansi yang bermoral, transparansi yang aspiratif dan transparansi yang memiliki notulen. Melalui "Transparansi Parsial" ini, penyelenggaraan pemerintahan mampu melaksanakan segala aktivitas kegiatan pemerintahan secara transparan.

\section{SIMPULAN}

Berdasarkan hasil penelitian disimpulkan sebagai berikut: 1) transparansi dalam penyelenggaraan pemerintahan sudah berjalan sebagaimana yang diharapkan di bidang anggaran, kepegawaian, pengadaan barang dan jasa. Ini terlihat di bidang anggaran telah dilakukan proses transparansi dalam penyusunan kebijakan umum anggaran, prioritas dan plafond anggaran sementara serta tahap pembahasan rancangan anggaran pendapatan dan belanja daerah belum jelas dalam pelaporannya; bidang kepegawaian berupa kegiatan rekruitmen, mutasi dan kompensasi; serta bidang pengadaan barang dan jasa berupa inventarisasi aset, melakukan legalitas audit, penilaian aset, optimalisasi aset, serta kegiatan pengawasan dan pengendalian, yang masih belum maksimal penerapan transparansinya dalam penyelenggaraan pemerintahan daerah; 2) sumber daya manusia yang bermental korupsi, aturan yang tumpang tindih, sistem keuangan yang lemah, lemahnya penegakan hukum dan masyarakat yang toleran merupakan faktor-faktor yang menjadi penghambat transparansi dalam penyelenggaraan pemerintahan daerah; 3) strategi "Transparansi Parsial" menjadi solusi yang tepat digunakan dalam menerapkan transparansi penyelenggaraan pemerintahan daerah. Melalui model ini transparansi penyelenggaraan pemerintahan yang baik dapat diwujudkan melalui akses informasi yang mudah diperoleh, mendapatkan empati yang penuh dari publik, memperbaiki moral kepercayaan publik, menerima aspirasi dari publik dan memiliki notulen yang dapat dipertanggungjawabkan.

\section{DAFTAR PUSTAKA}

Frederickson, H. George, 2007. Toward a New Public Administration. Revision Edition. The Minnowbrok Perspective Novato Chancler Publishing Company.

Helpenin, Jeniston, 2007. Application of Quality Service Theory. Published by John Wiley and Sons, New York.

Henry, F, 1995. The Public Service Administration. New York: Free Press. 
44|Ad'ministrare, Vol. 3 No. 2, 2016

Osborne, 2005. The Quest for Global Quality in Public Administration. Pustaka Delapratasa, Jakarta. (Diterjemahkan oleh Sutanto).

Ostrom, Donny, 1973. The Administration Public Service: Serving, not Steering, New York: ANSI.

Rakhmat, H., 2009. Teori Administrasi dan Manajemen Publik. Penerbit Pustaka Arif, Jakarta.

Rakhmat, Sartono, 2009. Memahami Good Governance dalam Kemitraan dengan Publik. Jakarta: PT. Grafindo Persada.

Salusu, J. 1996. Suatu Analisis Tentang Proses Pengambilan Keputusan Strategik pada Tingkat Manajemen Eksekutif Puncak; Studi kasus pada UNHAS. Disertasi (S3) UNHAS, Ujung Pandang.

Salusu, J. 2005. Pengambilan Keputusan Stratejik Untuk Organisasi Publik dan Organisasi Non Profit, PT. Grasindo, Jakarta.

Stelent, RF, 2008. The Service of Policy in Organization. John Wiley and Sons, New York.

Wilson, Wayne, 2007. A Introduction of Theory and Practice of Public Analysis. Northampton: Edward Elgar. 